\title{
Kyrgyzstan Universities' Profile in Terms of Preparing Students for the Future: Student Opinions
}

\author{
Yavuz Ercan Gul ${ }^{1}$ \\ 'Kyrgyz Turk Manas University, Educational Sciences, Kyrgyzstan \\ Email.ydidim@gmail.com
}

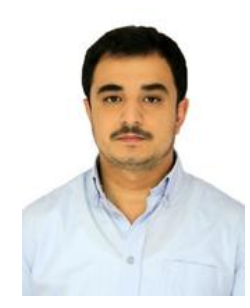

\begin{abstract}
Higher education in Kyrgyzstan has undergone a great deal of change in terms of quantity and quality since Kyrgyzstan's independence. Today, while there are many higher education institutions in the country, there are discussions about the quality of these institutions. The main purpose of this research is to determine the role of Kyrgyz universities in preparing students for the future. The research is designed as a mixed research design applying qualitative and quantitative data collection techniques together. For the qualitative data of the study, the research group consisted of 10 students and the quantitative data were collected from 312 students studying in three different universities. As a result of the research, it is understood that university students regard their universities as inadequate in terms of library, technological equipment, foreign language teaching, current craft knowledge, and social fields. The findings were discussed with other studies in the literature and some suggestions were made for the improvement of Kyrgyzstan universities.
\end{abstract}

Keywords: Kyrgyzstan, University, Student, Opinion, Problem, Higher education.

JEL Classification: Ioo, I23.

Citation | Yavuz Ercan Gul (2019). Kyroyzstan Universities' Profile in Terms of Preparing Students for the Future: Student Opinions. Asian Journal of Education and Training, 5(1): 97-105. History:

Received: 24 October 2018

Revised: 28 November 2018

Accepted: 3 January 2019

Published: 28 January 2019

Licensed: This work is licensed under a Creative Commons

Attribution 3.0 License (oc)

Publisher: Asian Online Journal Publishing Group
Funding: This study received no specific financial support.

Competing Interests: The author declares that there are no conflicts of interests regarding the publication of this paper.

Transparency: The author confirms that the manuscript is an honest, accurate, and transparent account of the study was reported; that no vital features of the study have been omitted; and that any discrepancies from the study as planned have been explained.

Ethical: This study follows all ethical practices during writing.

\section{Contents}

1. Introduction

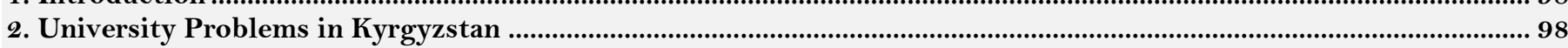

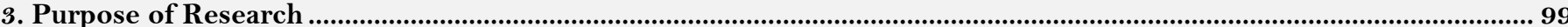

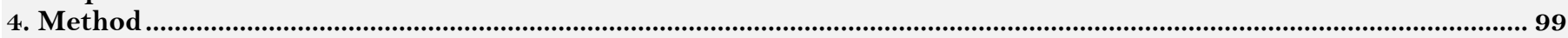

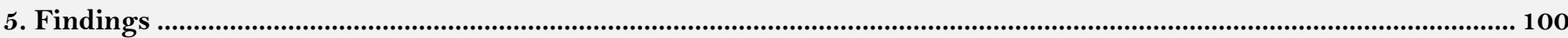

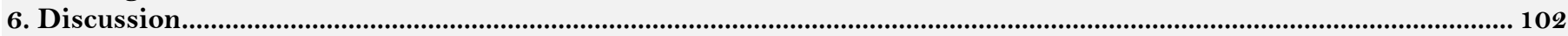

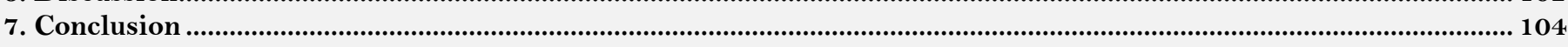

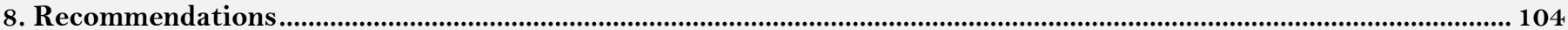

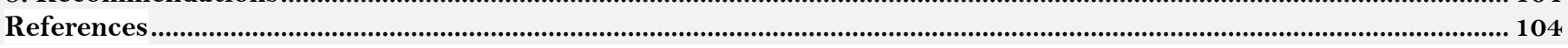




\section{Introduction}

With the separation from the Soviet Union, Kyrgyzstan has re-organized all its official institutions under the national program. As in all other formal education institutions, universities were also taken under the control of the Kyrgyz Ministry of Education and Science (Gül, 2015). Therefore, a centralized and monopolized higher education administration was formed.

Although Kyrgyzstan became a member of the Bologna process in higher education in 2011, universities did not succeed to be integrated into this system except for a few universities. In most universities, the education system is implemented in the form of the Soviet Union. In other words, the higher education system has a teaching model of a bachelor's degree with 5-year education including a master's degree (Madaminov, 2016). The students graduate with a master's degree from universities. There has always been an effort to improve the Kyrgyz higher education system with continuous reforms. In recent years, these reform movements are also continuing with an effort to change the centralized and monopolized education structure. Works on the empowerment of local governments are continuing (Kanimetov, 2015). In addition to trying to adapt to the Bologna process and conditions, Kyrgyzstan is a country where administrators are willing to integrate the higher education system into the European education system (Adamkulova, 2017).

According to 2011 data, there are 51 universities in Kyrgyzstan (16 foundations and 35 states) (www.stat.kg). 9,331 students from countries such as Kazakhstan, India, Russia, Turkey, Pakistan and Tajikistan study in these universities. University students coming from abroad play an important role in foreign cash flow. This is one of the means of living. In 2013 alone, 83.5 million dollars flowed into the country through foreign students. In other words, Kyrgyzstan is a collecting factory for students coming from abroad. However, the quality of education also decreases continuously. The knowledge of academics and students on instructional technologies is very weak (Mambetalieva, 2015).

According to UNICEF's 2013-2014 data, the number of students in Kyrgyzstan according to the language in higher education is calculated as Kyrgyz 55,773, while the number of students studying in Russian is 162,293. And again according to the data of UNICEF (2014) while 184.091 of the students studying in higher education consisted of Kyrgyz, the number of Russian students studying in higher education was calculated only as 15.581. This means that more than $70 \%$ of Kyrgyz students receive higher education in Russian (Savichev, 2014).

Today, there are 6 Russian universities in Kyrgyzstan. A total of 3185 students are educated in these universities. Kyrgyzstan ranks second among the Turkish Republics in terms of the number of Russian Universities and students studying after Kazakhstan (Vladimirovich, 2010). In addition, the Kyrgyzstan American University of Central Asia, which established by the USA, and the Kyrgyz-Turkish Manas University set up together by Turkey and Kyrgyzstan are located in Kyrgyzstan. Russian education is offered at the university and university branches of Russia, and English is offered at the American University. Kyrgyz-Turkish Manas University provides education in Kyrgyz and Turkish.

\section{University Problems in Kyrgyzstan}

Although there are dozens of universities in Kyrgyzstan, they couldn't succeed in education. Majority of the universities are gathered in the capital Bishkek. Foundation universities offer students high and dollar-based fees. State universities are also paid as foundation universities. However, the students who achieve outstanding success in the university entrance exam called ORT are not charged for studying at the state universities. Students who are not charged for university education constitute $10 \%$ of the total number of students (Zakirov and Ozakbegi, 2017). This brings along the problem of commercialization of universities. What students are required to have learnt upon graduation from university is determined by the state standard (GOS). But recently, the gap between the state standard and the knowledge of the university graduate students has increased (Orunbaev, 2011). But, the problems in the higher education system of Kyrgyzstan are not limited to this. According to Maslova (2016) the current education system is behind not only the world but also the needs of the Kyrgyz people. Proper education cannot be provided especially in the technical field and in accordance with the economic employment infrastructure (Zakirov and Ozakbegi, 2017). Despite the rapidly increasing number of universities and university students, the number of qualified staff is decreasing (Chontoev, 2016; Maslova, 2016). This shows that universities are insufficient in terms of training qualified staff.

While the unemployment rate in the country is increasing rapidly, the number of higher education graduates among these unemployed people is also increasing swiftly. One of the major reasons behind this is the insufficient education quality in universities. The professional qualifications of the teaching staff is also quite inadequate (Maslova, 2016). Nisharapova (2017) stated that Kyrgyz universities had no place in the international university rankings and that even the information regarding this could not be reached. In the report presented by the Committee on Education, Culture, Civilization and Information Politics of the Supreme Council of the Republic of it is stated that there are many universities in the country, but these universities do not affect the quality of higher education and the number of unemployed people who are university graduates in the country is increasing with each passing day.

Education in universities is given in the same way as in the Soviet Union Period. University buildings are the buildings of the USSR whose paints became chipped off, the classes are very narrow and gloomy, the corridors are narrow and old. There is very little or no elective courses at universities. The higher education problems in Kyrgyzstan can be listed as following (Mambetalieva, 2015):

- Inadequate financial condition in the higher education system

- Bribery

- Qualitatively and qualitatively poor teaching staff

- Education inconsistency between secondary and higher education

- Lack of modern libraries in universities

- Failure of university degrees and education to comply with the market economy

- Unable to find a job for university graduates. 
One of the problems in the universities of Kyrgyzstan is that the language of education is generally Russian. One of the reasons for this is that most of the textbooks are in Russian. In addition, many of the well-educated academicians have been educated in Russia and therefore have gained their professional knowledge in the Russian language. Kyrgyz students who come to the capital Bishkek especially from the rural areas have to learn the language before receiving a good education. A large part of the 5-years university education period is spent on language learning. For this reason, the students who are graduated from universities are also weak in their fields. (Khasanov, 2017).

Because of the high cost of living and the low salaries high-quality academicians who are trained in Kyrgyzstan choose to work abroad (Mambetalieva, 2015) as well as the rich and intelligent students (Ibraeva and Ismailova, 2016). Thus, the brain drain continues in Kyrgyzstan rapidly.

It can be seen from the above information that there is a problem of higher education in Kyrgyzstan. In this context, the opinions of the students studying in the universities of Kyrgyzstan are of importance because university students are the direct addressees of these universities and problems. If we can determine what the university students are dissatisfied with, we can also arrange the measures to be taken in the improvement of higher education in order of importance.

\section{Purpose of Research}

In this research, it is aimed to show the profile of Kyrgyzstan universities in preparing students for the future from the students' perspective. For this reason, data were collected through interviews and questionnaires.

\section{Method}

This research is designed as research which uses the phenomenology pattern (Aydın, 2015) as one of the qualitative research techniques that makes an in-depth analysis of the facts that we encounter in our lives, but do not have detailed knowledge of or do not reflect on. In addition, since the Questionnaire technique, which is a quantitative data collection technique, is used in data collection process, this research has attained a mixed pattern in which qualitative and quantitative research methods are used together.

Firstly, the focus group interview technique was used as one of the data collection tools under the Qualitative Paradigm (Silverman, 2013) which investigates how individuals understand the social world through their perceptions, attitudes and experiences. The focus group interview is carried out by the group members who can unite around a common problem through mutual interaction to seek answers to the questions posed by the interviewer (Karasar, 2016). In this way, it is aimed to understand what people really think about the research subject (Büyüköztürk, 2016).

Questionnaire technique was used to quantitatively test the accuracy of the information obtained through focus group interview and to contribute to the research results. The questionnaire technique is a research strategy where quantitative information is collected systematically from a relatively large sample taken from a population (Leeuw, 2008).

\subsection{Study Group}

The study group of the focus group interview consisted of 10 students, 3 girls and 7 boys studying at different universities in Kyrgyzstan. The study group of the research conducted with the questionnaire form prepared with the questions used in the focus group interview consisted of a total number of 312 students studying at 3 universities located in Kyrgyzstan's capital city Bishkek, namely Kyrgyz National University, Bishkek University of Social Sciences and Kyrgyz State University. In determining the study group of both applications, the Simple Random Sampling Technique was used in which everyone in the universe has an equal chance of being selected (Cochran, 1977).

\subsection{Data Collection}

\subsubsection{Focus Group Interview Data}

Firstly, a group of 5 students was interviewed about their expectations from a university in order to have a good future. In the light of the data obtained from the students as a result of the interview, 9 question sentences were created to be directed to the students during the interview. In order to test the functionality of the questions determined as a draft, a pilot interview was conducted with a group of 7 students and only a voice recording was made. At the end of the interview, it was seen that 2 questions produced similar data and it was decided to exclude one of the questions. In order to provide the scope validity of the questions to be used in the interview, the questions were presented to 3 lecturers in the field of Psychological Counseling and Guidance to examined in terms of comprehensibility and fitness for purpose. Based on the opinions of academicians, it was decided to use 8 questions in the research.

37 students from various universities and departments in Kyrgyzstan were interviewed and informed about the subject. Among them, 10 students considered eligible for the research were selected. Then, the room where the interview would be held as well as the things inside were determined. The camera and equipment for voice recording were prepared and placed. Assistance was received from a person as the moderator.

\subsubsection{Questionnaire Data}

Since the statements to be used in the questionnaire were previously presented to academicians in order to ensure the scope validity, this process was not deemed necessary to be repeated. The questionnaire form, which includes the 8 question statements prepared, was applied to 312 students from 3 universities in Bishkek, the capital of Kyrgyzstan. The data was written without being manipulated. 


\subsection{Data Analysis}

Focus group interview and questionnaire techniques were used in this research. Critical interpretive technique was used in the analysis of the data obtained. These technical data used in qualitative researches are subjected to critical analysis (Hatch, 2002; Woods, 2006).

\section{Findings \\ 5.1. Findings of the Data Obtained as a Result of the Focus Group Interview}

Table-1. Questions asked to the students during the interview and answers

\begin{tabular}{|c|c|c|c|c|c|c|}
\hline Item & $\mathbf{N}$ & 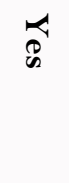 & 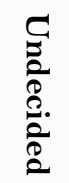 & z & $\bar{X}$ & $\partial^{\circ}$ \\
\hline Do you think you can get a good job related to your field after university? & 10 & 6 & 1 & 3 & 2.30 & 60 \\
\hline Is there enough technological equipment at the university? & 10 & 2 & 1 & 7 & 1.50 & 20 \\
\hline Do you think that your university gives an adequate level of professional knowledge? & 10 & 3 & 1 & 6 & 1.70 & 30 \\
\hline Are the library facilities at your university sufficient? & 10 & 4 & 2 & 4 & 2.00 & 40 \\
\hline Are the social areas of your university sufficient? & 10 & 1 & 2 & 7 & 1.40 & 10 \\
\hline Do you think that your teachers have sufficient knowledge and qualifications? & 10 & 5 & - & 5 & 2.00 & 50 \\
\hline Do you think that the teachings of the university are modern knowledge? & 10 & 1 & 1 & 8 & 1.30 & 10 \\
\hline Is foreign language teaching adequate at your university? & 10 & 1 & 2 & 7 & 1.40 & 10 \\
\hline
\end{tabular}

As it is understood from the table above, the question to which the students answered with "Yes" the most and the average of which is the highest $(\bar{X}=2.30)$ is the question about finding a good job in the future. Moreover, the question to which the students answered with "No" the most and the average of which is the lowest $(\bar{X}=1.30)$ is the question about the currentness of the knowledge provided at the university.

\subsubsection{Findings of the "Do you Think you can Get a Good Job Related to your Field after University?" Question}

According to the opinions about finding a good job after university, it is seen that 6 people $(\mathrm{S} 1, \mathrm{~S} 2, \mathrm{~S} 4, \mathrm{~S} 5, \mathrm{~S} 7$, S8) believe that they can find a good job, 1 person ( $\mathrm{S} 6)$ is undecided and 3 people (S3, S9, S10) do not believe. This statement has been the one with the highest average $(\bar{X}=2.30$. In general, students have high beliefs that they can find a job related to their field in the future. Some of the students stated that this was very difficult. One of the students (S2) said, "I believe, but I know that it will not be easy". One of the students who answered "Yes" to this question (S4) said "I believe but this has nothing to do with the university. Because this depends on the person. I believe that I will strive" in order to explain that this situation was not highly related to the universities.

One of the students (S10) explained the current situation of Kyrgyz students through a joke. The joke is as following:

"One day, they asked a student who had just started a university about what he would become in the future. He said he would be the president. In the second grade, they asked again and he said that he would be the prime minister, they again asked in the third grade and he said that he would be the deputy of the nation, they asked once again in the fourth grade and he said he would be the headman, and finally they asked one last time when he finished the university, and he said that he does not know where to go"

It was seen that the students who answered "yes" to this question were 1 st and 2 nd graders and those who answered "no" were 3rd and 4th graders. It is seen that there is a parallelism with the joke above told by the student. As the grades and ages of the university students progressed, these hopes were found to be reducing.

\subsubsection{Findings of the "Are there Enough Technological Equipment in the University?" Question}

It was seen that 2 students $(\mathrm{S} 1, \mathrm{~S} 5)$ said yes, 1 student $(\mathrm{S} 7)$ was undecided and 7 students $(\mathrm{S} 2, \mathrm{~S} 3, \mathrm{~S} 4, \mathrm{~S} 6, \mathrm{~S} 8$, $\mathrm{S} 9, \mathrm{~S} 10)$ said no. The majority of the students stated that technological facilities were insufficient in their universities. Students often complain about the lack of teaching technologies such as computers, projectors, smart boards, etc. in their universities. One of the students (S3) expressed the deficiencies in their schools saying "We don't even have a computer that students can use at our university".

One of the students (S6) commented on the situation by complaining, "There are many deficiencies at our university. We constantly have theoretical lessons. Either we write a lot or the lecturer tells the subject. We never see the computers. We don't even know if there are any". As can be seen from this comment, there are also shortcomings in the use of instructional technologies by the teachers.

One of the students (S8) stated that they had technological equipment in their universities but could not find time to use these devices. He described this situation as follows: As our courses are too much and long, we cannot find time to learn and use technological devices just as we cannot find any time for social activities. Our lessons last for 80 minutes, and there is a very short time break between the lessons". As can be seen from the above comments, the lessons are very long and we either listen to the lecturer or take notes. Lesson breaks are not long enough to meet the needs of the students.

\subsubsection{Findings of "Do you think your University Gives an Adequate Level of Professional Knowledge?" Question}

3 of the students $(\mathrm{S} 1, \mathrm{~S} 6, \mathrm{~S} 9)$ said "yes" to this question, 1 person $(\mathrm{S} 10)$ remained undecided and 6 people $(\mathrm{S} 2$, S3, S4, S5, S7, S8) said "no". One of the students stated that although the number of lecturers was too high, the lecturer themselves lacked professional knowledge. 
One of the students (S5) explained the answer to this question as follows: "The books of most branches are not translated into Kyrgyz. Therefore, neither can we learn enough, nor can the university provide. That's why research cannot be conducted" this student had chosen Kyrgyz as the language of education at the university. However, he complained about the lack of Kyrgyz resources or lack of up-to-dateness of the books. Another student (S3) also confirmed this situation and said: "We only know Kyrgyz. We cannot conduct researches as we do not know another language. We do not know whether the information given by the university is accurate or not."

One of the students (S7) saying that they did not have adequate lecturers at the university stated that some lecturers attended several courses even if they were not their field of subject. He expressed it as follows: "We do not have adequate lecturers at our university. For example, one lecturer attends three classes. And, they do not have sufficient knowledge". Another student stated that the course books were missing and therefore they could not learn on their own either.

\subsubsection{Findings of the "are the Library Facilities of your University Sufficient?" Question}

4 of the students $(\mathrm{S} 4, \mathrm{~S} 5, \mathrm{~S} 7, \mathrm{~S} 8)$ answered "yes", 2 people $(\mathrm{S} 2, \mathrm{~S} 9)$ answered "I have no idea" and 4 people (S1, S3, S6, S10) answered "no". The students complained that the books in the library were old and Russian. One of the students (S3) said "It does not help even if we go to the library because the books are from the period of the Soviet Union. The most part of the books are written in Russian".

One of the students (S2) complained by saying: "I don't know where the library is. I've never been there. Because there's no time. We can't read books because our courses are so long". When asked about the duration of the lessons, they said that they were 80 minutes with 10-minute breaks in between. It is understood from such comments that students cannot find the time for the library because of the long duration of the lessons in addition to the inadequacy of the libraries.

\subsubsection{The Findings of the "Are the Social Areas of your University Sufficient?" Question}

One person (S2) said "yes", 2 people (S4, S7) said "I have no idea" and 7 people (S1, S3, S5, S6, S8, S9, S10) said "no". This question was one of the lowest statements in terms of score average among the university qualifications. The students were asked what they understood from social areas. Students usually gave examples such as sports facilities, dining hall, cafeteria etc. In general, it was observed that the students complained about the lack of social areas in their universities and found their universities to be insufficient in this regard. One of the students (S3) expressed it by saying: "There are no opportunities for social activities. There are no areas where students can spend time besides the course periods".

One of the students (S4), giving a similar answer to the question about the library, said "Because of the long duration of the lessons, we do not have time to spend there even if there was a social area". And it was seen that some of the students had no idea about social areas. They defined their understanding of university life as attending the lessons and going back home when they finished.

\subsubsection{Findings of the "Do you think your Teachers have Sufficient Knowledge and Skills?" Question}

5 of the students (S3, S5, S7, S9, S10) answered "yes", and 5 people answered "no". In general, it was understood that the professional knowledge and skills of the teachers were average. One of the students (S3) said in order to explain the inadequacies of their teachers: "There are many teachers in our university, but the knowledge of these teachers is as old as our books. They were all brought up with the knowledge of the USSR period and they do not know the world out there". From this statement, it is understood that the lecturers are knowledgeable; however, their knowledge is old and they could not follow the developments in the world.

Another student (S5) said "our teachers lack responsibility rather than knowledge. They do not think about educating the students. And I also don't think that they are knowledgeable enough" The student demands more care and help for their development from their teachers. Therefore, it was seen that the "knowledge and skills" of the teachers were also understood as their communication and care with the students.

One of the students $(\mathrm{S} 7)$ said that their teachers were too old, that they had obsolete knowledge and lacked adequate information regarding the developments in the world. He also added "even if our university transitions to a modern system, this new system cannot be implemented without these teachers being replaced". In addition, one more student (S9) stated that their teachers were old.

\subsubsection{Findings of the "Do you think that the Teachings at the University are Modern Knowledge?" Question}

While 2 students $(\mathrm{S} 5, \mathrm{~S} 8)$ said "yes" to this question, 1 student $(\mathrm{S} 7)$ did not declare his opinion and 7 students (S1, S2, S3, S4, S6, S9, S10) said "no". A large part of the students, saying "no" to this question, stated that the information taught at their universities were old. One of the students (S2) expressed his dissatisfaction by saying "Definitely not up-to-date, no new resources arrive related to our field." Another student (S3) confirmed the previous one saying that "the information given is the information contained in the books that are left from the USSR period".

A student studying in the tourism department (S9) stated that their universities were far away from the developments in the world and that foreign language lessons were not taught in the tourism department. He also explained the lack of applied courses at their university saying that they were far behind the developments in the world in terms of tourism.

\subsubsection{Findings of the "Is Foreign Language Teaching Adequate in your University?" Question}

1 student (S6) said "yes" to this question and 2 students (S3, S8) stated that they were undecided and 7 students (S1, S2, S4, S5, S7, S9, S10) said "no" arguing that they were not given an adequate level of foreign language education in their universities. They claimed that students generally did not receive sufficient foreign language education in their universities. Especially, the student studying at the tourism department (S9) 
complained about this subject and said "Although our department is tourism, they do not teach foreign languages and our own teachers do not know any either."

One student who said "yes" to this question stated that he had been studying in the philology department and that his teachers had been educated in the country of the languages they taught, and therefore they had a good knowledge of the languages as well as teaching well.

\subsection{Findings from the Data Obtained as a Result of the Questionnaire Technique}

\begin{tabular}{|c|c|c|c|c|c|c|}
\hline & Range value & Min. & Max. & $\mathbf{N}$ & $\bar{X}$ & Ss \\
\hline Very Bad & (1) $1.00-1.80$ & \multirow{5}{*}{1.13} & \multirow{5}{*}{4.38} & \multirow{5}{*}{312} & \multirow{5}{*}{2.76} & \multirow{5}{*}{0.68} \\
\hline $\mathrm{Bad}$ & (2) $1.81-2.60$ & & & & & \\
\hline Average & (3) $2.61-3.40$ & & & & & \\
\hline Good & (4) $3.41-4.20$ & & & & & \\
\hline Very Good & (5) 4.21-5.00 & & & & & \\
\hline
\end{tabular}

As can be seen from the table above, the average of the students' responses to the questionnaire was calculated as 2.93. This shows that the students' opinion as to the contribution of their universities in preparing themselves for the future was "average". In general, students are of the opinion that their universities are insufficient to prepare themselves for the future.

Table-3. Students' opinions on each statement contained in the questionnaire

\begin{tabular}{|c|c|c|c|c|c|}
\hline Statements & Min. & Max. & $\mathbf{N}$ & $\bar{X}$ & Ss \\
\hline The possibility of finding a good job related to your field after university & 1 & 5 & 312 & 2.92 & 1.00 \\
\hline Adequate technological equipment at the university & 1 & 5 & 312 & 2.60 & 1.00 \\
\hline Provision of an adequate level of professional knowledge at your university & 1 & 5 & 312 & 3.30 & 0.94 \\
\hline Library facilities of your university & 1 & 5 & 312 & 2.40 & 1.23 \\
\hline Social areas of your university & 1 & 5 & 312 & 2.39 & 1.20 \\
\hline Sufficiency of your teachers' knowledge and skills & 1 & 5 & 312 & 3.54 & 0.87 \\
\hline The up-to-dateness of the information taught at the university & 1 & 5 & 312 & 2.61 & 1.09 \\
\hline Foreign language education at your university & 1 & 5 & 312 & 2.32 & 1.12 \\
\hline
\end{tabular}

The table above shows the arithmetic averages of the answers given by the students to the questionnaire statements. According to this, the area they considered their universities the most inadequate (2.32) was the subject of foreign language education. Based on the rating system of the questionnaire, it means "bad". Students are in general dissatisfied with the lack of foreign language education at their universities. The statement with the highest arithmetic average of the answers given by the students among the questionnaire statements (3.54) was the "proficiency of the knowledge and skills of the teachers" option. Students are generally satisfied with the knowledge and professional skills of their teachers. According to the rating system of the questionnaire, this means "good".

\section{Discussion}

In this section, because of the limited number of studies in the literature, the data obtained in this questionnaire were presented rather with an internal discussion.

\subsection{The Possibility of Finding a Good job Related to your Field after the University}

It was observed that students had a positive opinion about finding a job after they finished their universities. According to interview data, it was concluded that university students' beliefs with regard to finding a job in the future were higher than the questionnaire data. However, Orunbaev (2011) stated that there were problems in finding jobs and qualified employees in the market. In addition, Orunbaev (2011) and Maslova (2016) mentioning that universities were unable to provide qualified staff so students were in the belief of finding a job with their own efforts and studies. Sydykbaev (2015) pointed out this situation and said that the number of unemployed university graduates in the country was increasing continuously and that the universities should renew themselves in order to solve this situation. For this reason, it is thought that the beliefs of the students about finding a job stems from their own efforts rather than the contributions of the universities. In addition, it is seen that the 1 st and 2 nd graders of the university had high beliefs that they could get a job compared to the senior classes, causing the result to be high.

\subsection{Adequate Technological Equipment at the University}

This was found among the items with the lowest arithmetic average among the items in the research. The students think that the technological facilities in their universities are insufficient. The data from the questionnaire and the interview overlap. In addition, the report of the Committee on Education, Culture, Civilization and Information Politics of the Supreme Council of the Kyrgyz Republic (2008) on higher education supports the opinions of university students by mentioning the computer inadequacy in higher education. This situation can be explained by the inability to provide adequate technological facilities to educators in universities. According to Baran and Kahraman (2008) the ever-developing technology reveals new scientific devices that must be obtained in order to maintain the status of the universities. New books and journals must be purchased and subscribed to online databases. This means the increase in expenditures for Kyrgyz universities. When the financial condition of the universities is taken into consideration, they need to seek new fund sources. This is the only way the universities of Kyrgyzstan can keep in step with the modern world leaving the concept of the Soviet Union. It was 
observed that the students were thinking along the same lines with it. They said that they did not have a computer or did not know their location. In this respect, it is observed that university students in state universities in Kyrgyzstan experience shortcomings.

\subsection{Provision of an Adequate Level of Professional Knowledge at your University}

University students think that the professional knowledge given in their universities is average. It was seen that the data obtained as a result of the interview and the questionnaire data overlapped. According to the students' opinions, professional knowledge provided by the universities of Kyrgyzstan is neither sufficient nor insufficient. They also correspond with the information contained in the literature. In the study of Echo of Osh (2017) some of the universities of Kyrgyzstan were defined as a "diploma factory".

\subsection{Library Facilities of your University}

University students think that libraries of their universities are insufficient. This item dropped below the range of average points. It was observed that the data obtained from the interview and the scale data overlapped. This issue was also mentioned in the report of the Committee on Education, Culture, Civilization and Information Politics of the Supreme Council of the Kyrgyz Republic (2008) on higher education, and not only the university libraries but also the large archives and libraries in the country were mentioned as inadequate and old. This situation also coincides with the research data. Libraries are required for students to study and develop themselves out of school time. In particular, universities should be very wary about this situation. Mambetalieva (2015) pointed out this situation and stated that there are no modern libraries in the universities in the country, where there is open access to books, electronic search engines, and electronic access to international publications. The lack of libraries or their being inadequate or old gives insight into what are universities like and what is taught there. In other words, it cannot be expected that the universities of which libraries old and inadequate track the developments in the world and educates their students accordingly. The students also hold the same opinion.

\subsection{Social Areas of your University}

This was another statement the university students were dissatisfied with. In general, the data of the two pieces of research overlapped and the social areas of the universities in Kyrgyzstan were determined as insufficient. When asked about social areas, it was seen that the students understood sports areas, cafeterias, etc. and that they felt the need for such areas. Social areas are important places for students to socialize and discharge their negative energy. According to Erçevik and Önal, social spaces in universities are effective on students' individual and social development. Students take responsibility for participating in social activities during their university life and as part of social grouping. However, they learn to participate in communal living and to establish right relationships with the environment. They are raised as individuals ready for social relations. From this point of view, it is concluded that social spaces are important for students. Because the university is not only a place for students to learn but also where students' social personalities are developed, a sense of responsibility stems and they prepare for the future as part of a society in which they live. According to Kyrgyz students, universities in Kyrgyzstan do not fulfill these duties.

\subsection{Adequate Professional Knowledge and Skills of Teachers}

This was the statement that the students gave the highest scores among the questionnaire statements. Students were found to be generally satisfied with the knowledge and skills of their teachers. In addition, this item also had the second highest score among the interview data. Considering the literature, it was observed that there were studies on this subject. Sydykbaev (2015) one of those who conducted these studies, said that university teachers considered themselves very sufficient, but this did not reflect the truth. He expressed the necessity for conducting a serious examination on higher education staff. This information in the literature does not match the opinions of the students. Students are generally satisfied with their teachers. However, some of the students said that they were too old in the focus group interview and they were teaching with the USSR knowledge. It can also be thought that students evaluate their teachers' behaviors rather than their professional knowledge. Mambetalieva (2015) said that the teachers who are well-equipped and improved themselves among the academic staff in Kyrgyzstan choose to work abroad with a higher salary instead of their own countries with a low salary. It can be said that academician salaries, which are very low in Kyrgyzstan, affect the quality of the teaching staff.

\subsection{The up-to-Dateness of the Information Taught at the University}

When the qualitative data obtained from the interview were assessed, it was found that this item had the lowest score. When the survey data were evaluated, it was again found to be among the items with the lowest scores. It was seen that they got very close scores with the technological equipment in universities item, which is the second statement of the data collection tool. There is a close relationship between these two substances. The result also supports this. Universities are required to keep up to date the knowledge, materials, and knowledge of teaching staff. In this way, they will be able to ensure that the students graduating are a part of the society they live in as well as the modern world. In the opinion of the students, outdated information is taught in Kyrgyz universities and the curriculum falls behind with developments in technology in the world.

\subsection{Foreign Language Education at your University}

When the university students' answers to both pieces of research were evaluated, it was found that this item was one of the lowest scored items. In general, university students think that the universities they study do not teach foreign languages at an adequate level. In addition, the universities offer bilingual education in Kyrgyz and Russian languages. Students from rural areas have to learn Russian. This requires students to devote a certain part of their study time to learn the Russian language instead of professional development. Thus, they have no time to learn a third language. This is one of the reasons why students say they cannot learn foreign languages. Therefore, Kyrgyz students with better economic conditions prefer to study abroad in order to learn a foreign language. 
Students who do not have the opportunity to study abroad are studying at international private universities in Kyrgyzstan (Madaminov, 2016).

\section{Conclusion}

It was seen that the universities of Kyrgyzstan failed to prepare students for the future according to the students' opinions. According to the interview data, students stated that there was a lack of technological infrastructure in their universities. They said computers were not adequate and they had no smart boards. Another statement that could support this situation among the interview statements was the up-to-dateness of the information taught at the university. The students gave an "insufficient" and "old" answer to this statement as well. They said that the information and books used at the university remained from the Soviet Union period and that universities did not follow the developments in the world. It was observed that these two statements were below the average by getting almost the same score among the questionnaire scores. Therefore, the data of the two studies revealed the students' dissatisfaction in this regard.

Other statements that stayed below the average by taking close points both among the interview data and the questionnaire data were the insufficiency of the libraries and insufficiency of professional knowledge. Students expressed their dissatisfaction in these two issues. It was seen that there were students who did not know the location of the library. One of the reasons for this was determined as the lesson duration being too long and the lesson breaks being too short. In addition, the students said that the books taught at the universities were very old and therefore they did not respond to today's needs even if they received sufficient information about their profession. In addition to the library, university students stated that the social areas of the universities were also insufficient. In addition to their dissatisfaction with the intensity of their lessons, the students also stated that they were dissatisfied with the lack of places where they could spend time with their friends in their free time.

Foreign language education was the statement that the university students gave the lowest score in both the interview data and the questionnaire data and expressed their dissatisfaction for. It was understood that almost all of the students considered their universities deficient in this regard. As a reason for staying behind the professional knowledge in the world, the students argued that the foreign language, especially English, education was inadequate and at the same time, their teachers did not know them either.

Students stated that they wanted their teachers to pay closer attention to them and provide guidance. In terms of the sufficiency of their teachers' professional knowledge, students expressed their opinion as average. However, university students said that their teachers did not follow the developments in the world about their fields. All these results revealed the urgent need to improve the higher education in Kyrgyzstan and maintain integration with the world.

\section{Recommendations}

This study examines the problems of the higher education system in Kyrgyzstan from the point of view of students. It is understood that the students who are the direct objects of the education in Kyrgyzstan and who are at the center of the education system are not satisfied with the university education. They expressed that they are uncomfortable with almost all the statements of questionnaires and interviews. Accordingly, some suggestions have been made in order to improve and improve higher education in Kyrgyzstan.

The number of universities can be reduced and the quality of the universities can be considered more important rather than the number of universities.

The properties expected from a qualified staff can be determined by negotiating with the business market. Thus, qualified personnel can be trained according to the needs of the business market.

The integration process of the education system with the Bologna conditions can be accelerated, and academicians and universities can be harmonized with the world.

The budget allocated to the education system can be increased and thus financial support can be provided to successful academicians in order to increase the competition among them.

In order to let academicians know the world, various protocols can be signed with European countries and universities and academicians can be sent abroad for experience.

\section{References}

Adamkulova, C.W., 2017. Development of strategic management methods for the financial subsystem of universities in the conditions for the modernization of higher education and the transition to self-financing (on the Example of the Kyrgyz National University. J. Balasagyn). Bulletin of Tomsk State University. Economy, 39: 138-145. Available at: 10.17223 / 19988648/39/11.

Aydın, S., 2015. Case science research (2. bs.), M. Metin (Yay. Haz.). Within scientific research methods in education. Ankara: Pegem Academy. pp: 287-311.

Baran, T. and S. Kahraman, 2008. It the spirit of the age Tekn in universities: Contribution of information technologies to education. I. Civil Engineering Education Symposium, Antalya.

Büyüköztürk, Ş., 2016. Scientific research methods. 22th Edn., Ankara: Pegem Academy.

Chontoev, D., 2016. Higher education institutions of Kyrgyzstan need to improve the quality of education, 14: 115-116. Available from http://www.ktrk.kg/post/1939/ru [Accessed 12/21/2018].

Cochran, W.G., 1977. Sampling techniques. 3rd Edn., Toronto: U. S. Edition.

Echo of Osh, 2017. Education in Kyrgyzstan: Problems and ways of their solutions. Echo Osh Newspaper, 41: 11-12. Available from http://www.ehoosha.com/?module=opinion\&action=view\&id=1032 [Accessed 12/21/2018].

Gül, Y.E., 2015. Comparison of teacher training systems: The case of Germany and Kyrgyzstan. International Journal of Turkish Educational Sciences, 3(4): 68-83.

Hatch, J.A., 2002. Doing qualitativere search in education settings. New York: State University of New York Press.

Ibraeva, A. and R. Ismailova, 2016. Citizens of the Kyrgyz Republic's interest in study abroad. Manas Journal of Social Research, 5(1): 238256.

Kanimetov, E., 2015. Processes of democratization in the partnership system "University - School" of the Kyrgyz Republic. Bulletin of Modern Science, 1(2): 19-22.

Karasar, N., 2016. Scientific research method. Ankara: Nobel Publications.

Khasanov, N.B., 2017. Formation of professional competence of students of technical specialties oral communication in the practical course of the Russian language. Bulletin of the Kgusta, 2(56): 143-148. 
Leeuw, E.D., 2008. International handbook of survey methodology. 1st Edn., New York: European Association for Methodology Series. Routledge Press.

Madaminov, G., 2016. Preparation of schoolchildren for education at international universities. News of the Kyrgyz State Technical University Razakov, 4(40): 241-247.

Mambetalieva, M.B., 2015. Innovative marketing as a tool to increase exports of higher education in the Kyrgyz Republic. Bulletin of the International University, 138(6): 99-104.

Maslova, L.I., 2016. Internationalization of the higher education system of Kyrgyzstan in the conditions of integration of the countries of the Eurasian Conomic Union (EEA). Bulletin of KRSU, 16(2): 59-62.

Nisharapova, J., 2017. World university rankings: Case of the post-soviet countries and the need for participation of Kyrgyz universities. Alatoo Academıc Studies, 1(4): 199-203.

Orunbaev, T.A., 2011. Components of management and evaluation of educational services of universities in Kyrgyzstan. Journal of News of Universities, 7(1): 288-290.

Savichev, Y.N., 2014. About the status of the Russian language in Kyrgyzstan. Bulletin of the University of Russia Drujba Narodov, 3(4): $222-228$.

Silverman, D., 2013. What counts as qualitative research? Some cautionary comments. Quaternary Science Reviews Journal, 9(2): 48-55.

Sydykbaev, C.T., 2015. Easy to reduce, eliminate, and development of the compound. Journal of Kut-Bilim, 1(3): 26-27.

UNICEF, 2014. Education and science in the Kyrgyz Republic. Bishkek: A Statistical Compilation.

Vladimirovich, S.M., 2010. Education in Russian in central Asian States - CIS members: Problems and solutions. Scientific Journal "Problems of National Strategy, 3(7): 52-65.

Woods, M.D., 2006. Conducting a critical İnterpretive synthesis of the literature on access to healthcare by vulnerable groups. BMC Medical Research Methodology, 6(35): 1-13. Available at: 10.1186/1471-2288-6-35.

Zakirov, A. and M. Ozakbegi, 2017. Modern processes in the sphere of higher education of Kyrgyzstan. Alatoo Academic Studies, 2(4): $210-$ 214. 